\begin{tabular}{lc}
\hline & ANNALES \\
& UNIVERSITATIS MARIAE CURIE-SKŁODOWSKA \\
LOL. V & SECTIO N \\
\hline
\end{tabular}

ISSN: 2451-0491 • e-ISSN: 2543-9340 - CC-BY 4.0 • DOI: 10.17951/en.2020.5.283-298

\title{
Męka dwuznaczności i egzorcyzmy
}

\section{The Struggle of Ambiguity and Exorcisms}

\author{
Grażyna B. Tomaszewska \\ Uniwersytet Gdański. Wydział Filologiczny \\ ul. Wita Stwosza 55, 80-308 Gdańsk \\ g.tomaszewska@ug.edu.pl \\ https://orcid.org/0000-0001-9467-8426
}

\begin{abstract}
The topic of the study is one of the last poetry volumes by Czesław Miłosz entitled The Second Space (Pol. Druga przestrzeń), through which the author of the article looks at the complications of Miłosz's ambiguous religiousness. It is full of tension and contradictions to which the poet tries to address with various results. Miłosz avoids easy solutions, typical for common faith. The article talks about Miłosz's longing for the explicitness as a form of protest against evil and terror of this world, a form of protest against its ambiguous dimension, which forces the acceptance of passing, suffering, decay, death. It shows various forms of transgression of the antinomy created by the coexistence of beauty and the cruelty of life (i.a. experience of epiphany) and juxtaposes its specific character of his existential axiology.
\end{abstract}

Keywords: existential axiology; Miłosz's religiousness; contradiction; The Second Space

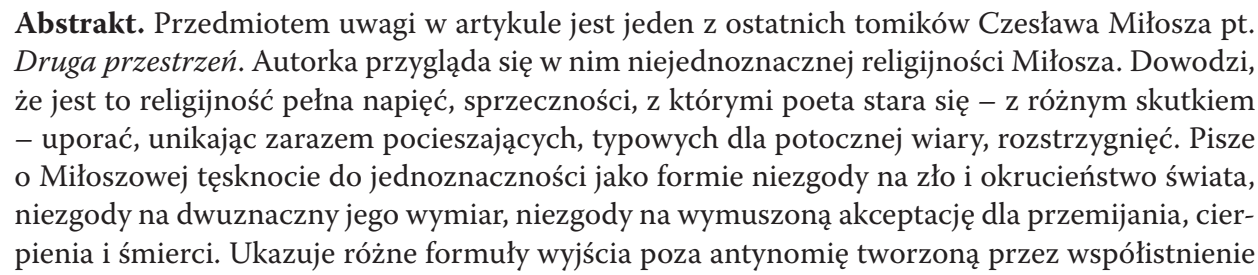


piękna i okrucieństwa życia (m.in. doświadczenie epifanii) i przedstawia na tym tle specyfikę Miłoszowej egzystencjalnej aksjologii.

Słowa kluczowe: egzystencjalna aksjologia; religijność Miłosza; sprzeczność; Druga przestrzeń

\section{TĘSKNOTA DO JEDNOZNACZNOŚCI}

W wierszu Nieprzystosowanie z tomu Druga przestrzeń, czytamy:

Nie nadawałem się do życia gdzie indziej niż w Raju.

Po prostu takie było moje genetyczne nieprzystosowanie.

Na ziemi ukłucie się kolcem róży zmieniało się w ranę, za każdym razem kiedy za obłok chowało się słońce, czułem smutek.

Udawałem, że jak inni pracuję od rana do wieczora, ale nieobecny, powierzony niewidzialnym krajom.

Dla pociechy uciekałem do miejskich parków, żeby patrzeć i wiernie malować kwiaty i drzewa, ale te z rzeczywistych zmieniały się w rośliny rajskiego ogrodu.

Nie pokochałem kobiety moimi pięcioma zmysłami, chciałem w niej widzieć jedynie siostrę sprzed naszego wygnania.

Religię ceniłem za to, że na tej ziemi bólu

była pieśnią żałobną i proszalną. (Miłosz 2002: 32)

"Genetyczne nieprzystosowanie" mówiącego przywołuje marzenie o świecie, w którym róża jest wyłącznie czystym pięknem, słońce nigdy nie chowa się za chmury, praca nie jest nużącym obowiązkiem, a idealna miłość duchowej siostry nie naraża nas na cierpienia i rozczarowania niesione przez związek z osobą kochaną i kruchą, bo zanurzoną w cielesności. Świat bez bólu, smutku, bez mozołu pracy, ale głównie bez męczącej dwuznaczności. Bo przecież na tej „ziemi bólu” jest róża, jest słońce, jest łącząca ludzi praca, są miejskie parki z kwiatami i drzewami, w których można szukać „pociechy”. W końcu jest i miłość. Jednak podmiot widzi tylko „ziemię bólu”, bo każdy z tych elementów nie jest dość czysty i jednoznaczny. 
„Nieprzystosowanie” wypowiadającego się jest wyrazem braku zgody na dwuznaczną jakość rzeczywistości. Jeśli za pięknem ukrywa się cierpienie, to istnieje tylko cierpienie. Jeśli za wszystkim ukrywa się ból i śmierć, to istnieje tylko ból i śmierć. A na „ziemi bólu” można wznosić wyłącznie „pieśni żałobne i proszalne". One też tworzą fundament wartości, jaką nadaje się religii. Wartości - trzeba przyznać - dwuznacznej, gdyż przyzwalającej na wyobcowanie z realnego świata, na „udawanie" tylko, że dzieli się wysiłek i odpoczynek z innymi, gdy jest się "nieobecnym / powierzonym niewidzialnym krajom”. Rzeczywiste rośliny zamienia się „w rośliny z rajskiego ogrodu”, a w kochanej osobie chce się „widzieć jedynie siostrę sprzed naszego wygnania”. W rezultacie świat materialny oddaje się nicości, jakby nie miał żadnego znaczenia. Religia staje się wówczas pretekstem, by można było wziąć w nawias wszystko, czego nie można znieść. A nie można znieść świata, który dając piękno, daje równocześnie cierpienie. Takie „genetyczne nieprzystosowanie”. Wprawdzie kategoryczność pragnienia jednoznaczności ociera się tutaj o rodzaj autoironii, ale nie wycisza ona samego problemu. Jest tylko śladem, zarysem świadomości, że niezgoda „genetycznie nieprzystosowanego" mogłaby z jednej strony zbyt łatwo tłumaczyć formy "zdrady” wobec ułomnego świata, a z drugiej być znakiem bezradności wobec pragnień niemożliwych i z góry skazanych na klęskę.

W Rodzinnej Europie, mówiąc o młodzieńczych fascynacjach duchowych nurtami gnostyckimi i manicheizmem, Miłosz wyjaśnia, że zaspokajały one „skrajne skłonności młodzieńczej duszy”, która „chce [...] rozstrzygnąć: niech będzie albo, albo" (Miłosz 1990: 83). Albo istniejący świat jest dobry, albo jest zły. Jeśli jest zły, jego twórcą nie może być dobry Bóg. Gnostycyzm i manicheizm są wyrazem potrzeby jednoznaczności, kiedy nie usuwamy ze świadomości skandalu zła, chyba że go wyciszamy lub w monoteistycznym Bogu - jak to robi Carl Gustaw Jung (1995: 161, 191) - ujrzymy niejednoznacznego Boga sprzeczności, mieszczącego w sobie i miłość, i zniszczenie.

Mimo starań związanych z ujednoznacznieniem koncepcji Boga w judaizmie i chrześcijaństwie (Ricoeur 1986: 226) Bóg sprzeczności zawsze towarzyszył oficjalnym doktrynom, bo był obecny w religijności mistycznej. Współtworzył m.in. obraz Boga kabalistów (Scholem 1997: 202-203) czy Jakuba Boehmego. W koncepcji Boehmego negatywność, zło są elementami Boskiej ciemnej energii, niezbędnej dla istnienia i rozwoju świata czy dla życia w ogóle (Bieńkowska 1979:

1 Według Stefana Chwina (2012: 103-129) wiersz ten wpisuje się w Miłoszowy gnostycki „dyskurs nieistnienia”, którego obecność można jego zdaniem (bardzo przekonującym) zauważyć w całej twórczości Miłosza. 
90-93, 98). O uwzględnienie dwuznaczności sfery sakralnej w życiu i w sztuce upomina się współcześnie chociażby Jerzy Nowosielski:

[...] trzeba sobie uświadomić, że sacrum posiada aspekt nie tylko chwalebny, nie tylko jest czymś, co określamy pozytywami najwyższej rangi, jakie tylko potrafimy wymyślić. Sacrum od tysiącleci w świadomości człowieka posiada aspekt również kenotyczny, wskazujący na to, co jest po prostu niszczeniem, jest katastrofą, jest rozdarciem, jest dramatem. (Nowosielski 2013: 151-152)

A jednak dwuznaczność sacrum, o której pisze Nowosielski, dwuznaczność Boga są trudne do przyjęcia. Są możliwe do przeżycia w doświadczeniu mistycznym, do akceptacji jako ogólna zasada, lecz przełożone na bezpośrednie doświadczenie bólu i cierpienia w namacalnej rzeczywistości, porażają okrucieństwem. I wcale nie jest ono mniejsze, jeśli w Bogu umieści się jego źródło.

\section{MĘKA DWUZNACZNOŚCI}

Nakreślona w Nieprzystosowaniu tęsknota do jednoznaczności jest udziałem każdego. Wiersz ujawnia równocześnie cenę owych tęsknot: wyobcowanie z realnej rzeczywistości i opuszczenie realnych ludzi. Tylko że używane wielokrotnie w przeszłości (przez manichejczyków, gnostyków, a także Ojców Kościoła) argumenty na rzecz „marności świata tego” nie przekonują tęskniącego do jednoznaczności bohatera późnych wierszy Miłosza. Nieprzystosowanie z tomu Druga przestrzeń poprzedza inny wiersz:

\section{POWINIENEM TERAZ}

Powinienem teraz być mądrzejszy, niż byłem.

Ale nie wiem, czy mądrzejszy jestem.

Pamięć układa historię wstydów i zachwyceń.

Wstydy zamknąłem w sobie, ale chwila zachwytu pręgą słońca na ścianie, trelem wilgi, twarzą, irysem, tomikiem wierszy, człowiekiem trwa i powraca w blasku.

Ta chwila mnie podnosi nad moją ułomność.

Wy, w których się kochałem, zbliżcie się, przebaczcie mi moje winy z uwagi na moje olśnienie waszą pięknością. 
Nie byłyście doskonałe, ale dla mnie ten wykrój brwi, to pochylenie głowy, ta mowa zalotna a wstrzemięźliwa mogły należeć tylko do istot doskonałych.

Przysięgałem kochać was wiecznie, ale potem słabło postanowienie.

Z migotliwych spojrzeń utkana jest moja kraina, nie starczyłoby jej na owinięcie monumentu.

Zostałem z nie napisanymi odami na chwałę wielu kobiet i mężczyzn.

Ich nieporównana dzielność, ofiarność, oddanie przeminęły razem z nimi, i nikt o nich nie wie. Nikt nie wie na całą wieczność.

Kiedy o tym myślę, potrzebuję nieśmiertelnego Świadka, żeby on jeden wiedział i pamiętał. (Miłosz 2002: 29-30)

Gdyby świat widzialny był marnością, byłoby łatwiej. Ale nie jest. Potrafi być godny najwyższego podziwu. Przeżywane dzięki niemu „chwile zachwytu” dają wolność. Nie jest się wtedy zdeterminowanym przez własne „ułomności”, nie paraliżuje nas wstyd, nie ogranicza niewiedza czy niepewność. Dzięki takim chwilom wstępujemy do świata doskonałego. Gromadzone w pamięci, „trwają i powracają w blasku", chroniąc nas przed niespełnionymi oczekiwaniami („Powinienem teraz być mądrzejszy, niż byłem / Ale nie wiem czy mądrzejszy jestem”) czy wyrzutami („historia wstydów”). Dotyczą różnych rejonów rzeczywistości: „pręg słońca na ścianie”, śpiewu ptaka, twarzy, kwiatu irysa, „tomiku wierszy" czy człowieka w ogóle. Obrazy kochanych niegdyś kobiet przywołują poczucie, że przebywało się wśród „istot doskonałych”. Podobna świadomość towarzyszy wspomnieniom o wielu kobietach i mężczyznach ze względu na ich „nieporównaną dzielność, ofiarność, oddanie”.

Jednak zachwyt głoszony z perspektywy życia, w którym dokonuje się jego podsumowania („powinienem teraz być mądrzejszy”), jest równocześnie przejmującym lamentem. Pamięć oczarowania to tylko „z migotliwych spojrzeń utkana [...] kraina". Nie ma w niej materiału na zbudowanie czegoś trwałego, rzeczywiście ocalającego („nie starczy jej na owinięcie monumentu”). Żal jeszcze większy rodzi świadomość, że „chwała wielu kobiet i mężczyzn” dla „ich 
nieporównanej dzielności, ofiarności, oddania" nie znajdzie żadnego kronikarza, który by ją nawet fragmentarycznie utrwalił (o problemie pamięci zawodnej, selektywnej, rodzącej poczucie winy zob. Biedrzycki 2011: 497, 542-551). Cóż po doskonałości, skoro wraz z ludźmi ginie i „nikt o nich nie wie. / Nikt nie wie na całą wieczność".

Jedna z myśli w Albo-Albo Sørena Kierkegaarda (2010: 18) brzmi: „Najlepszym dowodem potwierdzającym nędzę istnienia jest ten, który się osiąga z rozmyślań nad jego (istnienia) wspaniałością".

Powyższy paradoks zdaje się być udziałem także podmiotu lirycznego wiersza. Broniąc się przed nim, „potrzebuje nieśmiertelnego Świadka”, który by ocalał nietrwałe doskonałości świata i uwalniał go od dwuznaczności wynikającej $\mathrm{z}$ doświadczenia, że to co doskonałe, także jest skazane.

Co prawda, ten „Świadek” funkcjonuje niczym rodzaj magicznego zaklęcia, podobnie jak Miłoszowa idea apokatastasis (idea przywrócenia wszystkiego do istnienia w pełnej chwale), do której uporczywie powraca. Ale stałym współrytmem jego zaklęć są zwątpienie i niepewność, ujawnione bezpośrednio np. w wierszu A jeżeli:
A jeżeli to wszystko jest tylko snem
Ludzkości o sobie? I my, chrześcijanie,
Śnimy swój sen wewnątrz snu?

I jeżeli nikt nie jest odpowiedzialny za nasze złudzenie,

Z którym schodzimy pod ziemię,

Oczekując, że nas podniesie Wieczna Sprawiedliwość? (Miłosz 2002: 57)

Wielokrotnie podkreślano Miłoszową potrzebę sakralizacji świata i jego niechęć do buntu czy bluźnierstwa (Tomaszewski 1998: 222-224). Wiersz Powinienem teraz wskazuje na jedną z przyczyn. Otóż ani bunt, ani bluźnierstwo nie ocalają , nie tworzą narzędzia obrony przed żarłocznością nicości. Są tylko innymi rodzajami przyzwolenia na towarzyszącą wszelkim przejawom życia muzykę „zgrzytliwego obrotu piekielnych kół” (Miłosz 2002: 78). A tej zgodzie Miłosz się przeciwstawia, szukając dla człowieka jakiejś przestrzeni nadziei.

Religia buduje jeden z języków niezgody na "grozę w kamiennym porządku świata" (tamże: 68). Pozwala na zawieszenie jednoznaczności rozstrzygnięcia i zbudowanie na nim nadziei, jak to ukazuje wiersz Na próżno: 
Przygotowani na to, że dźwignie się z otchłani zimna ręka, żeby nas wciągnąć razem z naszym

niedokończonym budowaniem.

Ale wierząc, że niektórzy z nas otrzymają dar, łaskę wbrew sile ciążenia. (tamże: 68)

Z jednej strony „dar, łaska / wbrew sile ciążenia” zawieszają jednoznaczność (wyłączność) otchłannej i pochłaniającej wszystko „zimnej ręki”, jednak z drugiej strony wyciągająca się po nas „z otchłani zimna ręka” zawiesza jednoznaczność (pewność, wyłączność) wiary w „dar, łaskę / wbrew sile ciążenia”. W efekcie nie ma ucieczki przed męczącą dwuznacznością, bo przebywamy w kręgu sprzeczności nierozstrzygalnych, nietworzących szansy na jakąkolwiek formę uspójniającej je syntezy (Sławek 2011: 279), sprzeczności współtworzących Miłoszowy obraz świata $^{2}$ (Jastrzębski 2011: 245; Klejnocki 2011: 634; Stala 2011: 133).

\section{EGZORCYZMY}

\section{Zawieszenie alternatywy (albo-albo)}

Kierkegaard zwraca uwagę na paradoks ludzkich wyborów, którym przewodzi pragnienie jednoznaczności, dowodząc, że w istocie podkreślają one jedynie ludzkie zaplątanie:

Śmiej się z tarapatów życia, będziesz tego żałował; płacz nad nimi, będziesz także tego żałował; śmiej się, czy płacz z tarapatów życia, będziesz i tego, i tego żałował; albo będziesz się śmiał, albo będziesz płakał, będziesz żałował i tego, i tego. (Kierkegaard 2010: 28-29)

Nie ma szansy, by sprzeczności poddać jakiejś „,mediatyzacji”, dlatego - jak czytamy - „prawdziwa wieczność nie leży w »albo-albo«, ale poza wyborem” (tamże: 29). Miłosz w tomie Druga przestrzeń szuka perspektywy „poza wyborem”, ale i ona wymusza jakąś formę zgody na dwuznaczność świata, której - w przeciwieństwie do dwuznacznej świadomości ocalenia - dać nie chce, gdyż zbyt jej blisko do praw ziemi, w których głosi się „triumf silnych i przegraną słabych”, akceptację śmierci

2 Nie wiem, czy rzeczywiście - jak sugeruje Zofia Zarębianka (2014: 256) - owe sprzeczności przyczyniają się do „procesualnego dojrzewania” (na podobieństwo Heglowskiej triady) i osiągania wyższych stopni duchowej świadomości przez ja liryczne jego utworów. 
dla wszystkiego, „co biega, pełza, lata” (Miłosz 2002: 68). Dlatego potrzebuje kogoś, kto wysłuchuje błagalnych modlitw i wnosi „współczucie, litość, zrozumienie” w nieczuła „obcość pośród galaktyk” (tamże: 78). Potrzebuje Go ze względu na powstrzymanie zgody, że świat już taki po prostu jest.

Zdaniem Agaty Bielik-Robson (2012: 8) problematyczność jest fundamentalną cechą ludzkiego bytu. Wynika ona ze specyfiki ludzkiej energii witalnej, która - jak pisze - „nie tylko nie nadaje się do życia, ale wręcz życiu się przeciwstawia”. Rozwój sfery psychicznej jest efektem szukania sposobów na poradzenie sobie z tą pierwotną niezdolnością. Chcąc przetrwać, człowiek musi dokonać podstawowego wyboru: „wmówić sobie albo życie, albo śmierć” (tamże). Jeśli wybierze śmierć (wybór "tanatyczny”), to ona określi jego egzystencję, intensyfikując jej problematyczność, jako trwanie w ustawicznej sprzeczności. Wybór życia ma z kolei dwojaki charakter. Może polegać na próbie bezrefleksyjnego przystosowania się do innych bytów przyrodniczych (akt „biomorfizmu”) lub na świadomym i refleksyjnym "biofilicznym” akcie wyboru (tamże). Tylko wybór tanatyczny i biofiliczny, co zaznacza Bielik-Robson, są wyborami ludzkimi, gdyż akt biomorfizmu prowadzi do renaturalizacji człowieka (tamże: 9). Z kolei dwa ludzkie sposoby radzenia sobie z problematycznością życia są skrajnie różne. W pierwszym, charakterystycznym dla myśli greckiej, życie postrzega się jako błąd, chorobę, brak. W drugim, charakterystycznym dla myśli hebrajskiej, problematyczność ludzkiego życia traktuje się nie tyle jako błąd i brak, ile jako szansę i obietnicę życia spotęgowanego, wyzwolonego z powielania tylko mechanizmów natury (tamże: 9-10). W rezultacie Bielik-Robson zasadniczej różnicy między Atenami i Jerozolimą (myślą grecką a hebrajską) upatruje w skrajnie odmiennym stosunku do problematyczności ludzkiego życia - grecko-tragicznej negacji przeciwstawia żydowsko-mesjańską jego afirmację (tamże: 12). W imię życia, jako obietnicy życia spotęgowanego, postuluje „imperatyw wyjścia z tragedii jako układu domyślnego zachodniej refleksji”, „przełamanie tej tragicznej hegemonii i wykreślenie alternatywy, jaką jest mesjańska obietnica »życia powiększonego «" (tamże: 13).

Czy jednak rzeczywiście można myślowo dokonać przejścia na stronę witalizmu mesjańskiego, opuszczając równocześnie „tragiczną hegemonię” myśli greckiej? Czy naprawdę możemy wyzwolić się z dwuznaczności związanej ze stosunkiem do problematyczności życia? Czy „albo-albo”, związane z myślą grecką albo hebrajską, mimo myślowej rozłączności, nie mieszkają we wspólnym pokoju? Tak zdaje się to wyglądać w twórczości Miłosza, uwikłanego z jednej strony w „tragiczną hegemonię" obrazu życia jako niedopełnienia, braku, bólu (Nieprzystosowanie), a z drugiej sławiącego przejawy jego pełni, doskonałości, których tylko nie chce się oddać na zatracenie (Powinienem teraz). 


\section{Romantyzm}

Propozycję wyzwolenia z męczącej alternatywy „albo-albo” odsłania także romantyzm odczytany w duchu Michała Pawła Markowskiego, a zwłaszcza Agaty Bielik-Robson. Markowski doszukuje się w nim źródeł nadziei dla współczesnego człowieka, który istniejąc już w świecie odczarowanym, może dzięki procesowi romantyzacji (tj. ponownego „zaczarowania”, by życie odzyskało tajemnicę i magię) nadać mu całościowy (holistyczny) sens (Markowski 2013: 310). To sens wynikający z procesu potencjonalizowania życia, a więc otwierania go na niekończącą się wielość jego możliwości, „czyli - nieskończonych możliwości interpretacji” (tamże: 344).

Miłosz podejrzewa romantyzm, podążając śladem typowych o nim wyobrażeń, o fałszywy rodzaj duchowości, która prowadzi do wyabstrahowania człowieka ze świata i jego nieszczęść, przenosząc go na „wyspę poetycznych rojeń” (Miłosz 1980: 44). Dokonując współczesnej rewizji romantyzmu, Bielik-Robson zwraca uwagę, że romantyczny, opuszczający świat zmysłowy „idealizm” jest efektem nieporozumienia związanego z koncepcją specyfiki romantycznego $J a$. Nie jest ono $J a$ transcendentalnym, kontynuującym tradycje idealistyczne (znajdujące swój najpełniejszy wyraz w Heglu), lecz „duszą czującą”, w której duchowe istnieje w ścisłej relacji z materialnym. Istnieje jako „świadomość wpływu", a więc świadomość próbująca $\mathrm{z}$ wielkim trudem dokonać połączenia prawdy doświadczenia związanego z realną rzeczywistością i prawdy doświadczenia wewnętrznego. Trwanie w niezniesionym paradoksie prawd sprzecznych nie wyklucza zdaniem Bielik-Robson przyswajania tego, z czym toczy się spór (Bielik-Robson 2004: 27-31, 41). Przy czym etosem „duszy czującej” $\mathrm{w}$ jej przekonaniu nie jest sama walka ani też - w przeciwieństwie do projektu Markowskiego - sama idea potencjonalizacji życia realizująca się poprzez pasję dyskursywno-interpretacyjną, lecz zbawienie. Zbawienie rozumiane jako przeżywanie chwil epifanii szczęśliwych, kiedy aporie ulegają zawieszeniu, a „upiorna dysjunkcja" sprzeczności Ja ze światem przekształca się w koniunkcję, a więc dochodzi do „pojednania ze światem takim, jakim mógłby być, wyrwany - przez Wizję i Poezję - z kręgu ontycznej przemocy, gdzie nie rządzi sens, lecz tylko naga siła" (tamże: 495; Bielik-Robson 2008: 152-153).

Koncepcja romantycznej „duszy czującej” wydaje się być bliska również autorowi Ziemi Ulro. Może i „romantyczna” potrzeba ustawicznej negocjacji duchowego z rzeczywistym nie pozwala Miłoszowi być wyznawcą „poezji czystej”. Może „nieczystość”, o której pisze Andrzej Franaszek (2014: 31), jest jakąś zbawczą formułą egzorcyzmowania nieczułości i bezwzględności świata czy sprzeciwu wobec zgody na zostawienie świata tylko jego nieczułości. 


\section{Epifanie - szczęśliwe koniunkcje}

Zdaniem Romana Ingardena każde wartościowe dzieło sztuki, bez względu na czas powstania, zawsze jest efektem przeżycia epifanii, a więc przeżycia - jak je nazywa - objawiających nam się od czasu do czasu jakości metafizycznych. Nadają one wybranym elementom codziennej egzystencji wartość szczególną, rewelatorską, przekształcającą je w „zdarzenia” stanowiące „szczyt, a zarazem głębię naszego życia i wszystkiego tego, co istnieje" (Ingarden 1960: 369). Zapis powyższych przeżyć w sztuce nigdy nie jest pełny, zawsze przypomina bowiem "dalekie odblaski”, ale to ze względu na nie („odblaski”) odbiorca szuka z nią kontaktu (tamże: 370-371). W rezultacie - co wyraziście zaznacza Władysław Stróżewski (2002: 114) - każda prawdziwa sztuka ma charakter metafizyczny czy też, mówiąc innym językiem, epifanijny³.

W przekonaniu Jana Błońskiego epifanie Miłosza charakteryzuje iluminatorska pewność prawdziwości odsłanianego, objawianego. Ostrości i wnikliwości widzenia towarzyszy równocześnie „przelotność, fantasmagoryczność”, krótkotrwałość (Błoński 2011: 49). Rzeczy - podobnie jak w przeżyciu jakości metafizycznych u Ingardena - nie są jakimiś symbolicznymi znakami odsyłającymi do świata idei, ale istnieją same dla siebie w swym indywidualnym tylko, osobniczym kształcie. Spowite są jednak w aurę niezwykłości, podkreślającej tym mocniej ich niepowtarzalność (tamże: 51-53).

Błoński podkreśla rolę Erosa, zmysłowej fascynacji w Miłoszowych epifaniach (tamże: 59), którym towarzyszy podejrzenie, że wszystko co zmysłowe, naznaczone jest skazą nietrwałości. Dlatego jego ekstazy mieszają się ze zwątpieniem i świadomością braku (tamże: 59-62). Aby ocalić chwilowe i przelotne, Miłosz ratuje się ideą apokatastasis, tj. ideą przywrócenia wszystkiego, co stworzone do istnienia w pełnej chwale (tamże: 67-68). Wyraża ona zdaniem Błońskiego finalny cel wszelkich jego twórczych działań: „Jest ostatnią epifanią, ponownymi narodzinami, ostatecznym ocaleniem" (tamże: 69). Idea apokatastasis byłaby więc jedyną epifanią szczęśliwą i zaspokajającą Miłoszową tęsknotę do jednoznaczności. Ale Błoński (tamże: 70) zdaje się przeceniać jednoznaczność i pewność wiary autora Drugiej przestrzeni.

Zdaniem Ryszarda Nycza (2001: 169) epifanie Miłosza wyrażają „zaszyfrowany ślad obecności utrwalony w przeżyciu, pamięci, języku - przez podmiot [...], który poręcza, legitymizuje jej prawdziwość". Mają różny charakter, ale niektóre z nich przypominają „drzwi obrotowe, ukazując nam w tym samym

3 O koncepcji dzieła jako epifanii pisze również, przejmując tę ideę od Charlesa Taylora, Ryszard Nycz (2001: 45). 
»wielowarstwowym konkrecie« historię i trwanie, rozkład i scalanie; czasowość i pozaczasowość poszczególnych istnień, z których składa się, nieobjęty i nieosiągalny, świat" (tamże: 171).

Wprawdzie większość Miłoszowych epifanii, na co zwracają uwagę różni badacze, uruchamia tęsknotę do wyzwolenia - mówiąc za Bielik-Robson $\mathrm{z}$ „upiornej dysjunkcji”, ale osiągane stany koniunkcji nigdy nie są czyste, a więc prawdziwie zbawcze. Są próbami egzorcyzmowania nicości, ale próbami tym mocniej podkreślającymi jej władzę. Nie ma w nich czystej radości istnienia, tak podziwianej przez Miłosza np. w Рanu Tadeuszu Mickiewicza (Miłosz 2010: 92-93).

Jednak i u Miłosza można znaleźć przykłady epifanii szczęśliwych, np. w wierszach Dar i Łąka (o specyfice harmonii, odczuciu szczęścia w tych utworach zob. Klejnocki 2011: 634; Pilch 2008: 146, 155-156; Stala 2011: 148-149; Zarębianka 2014: 412-418, 484). Zapis jednej z nich znajduje się również w utworze Esse. Poświadcza się wprawdzie tutaj aporie między $J a$ a światem, ale równocześnie się je zawiesza, bo to nie one nadają główny ton przeżyciu.

\section{ESSE}

Przyglądałem się tej twarzy w osłupieniu. Przebiegały światła stacji metra, nie zauważałem ich. Co można zrobić, jeżeli wzrok nie ma siły absolutnej, tak żeby wciągał przedmioty z zachłyśnięciem się szybkości, zostawiając za sobą już tylko pustkę formy idealnej, znak, niby hieroglif, który uproszczono z rysunku zwierzęcia czy ptaka? Lekko zadarty nos, wysokie czoło z gładko zaczesanymi włosami, linia podbródka - ale dlaczego wzrok nie ma siły absolutnej? - i w różowawej bieli wycięte otwory, w których ciemna błyszcząca lawa. Wchłonąć tę twarz, ale równocześnie mieć ją na tle wszystkich gałęzi wiosennych, murów, fal, w płaczu, w śmiechu, w cofnięciu jej o piętnaście lat, w posunięciu naprzód o trzydzieści lat. Mieć. To nawet nie pożądanie. Jak motyl, ryba, łodyga rośliny, tylko rzecz bardziej tajemnicza. Na to mi przyszło, że po tylu próbach nazywania świata umiem już tylko powtarzać w kółko najwyższe, jedyne wyznanie, poza które żadna moc nie może sięgnąć: ja jestem - ona jest. Krzyczcie, dmijcie w trąby, utwórzcie tysiączne pochody, skaczcie, rozdzierajcie sobie ubrania, powtarzając to jedno: jest! I po co zapisano stronice, tony, katedry stronic, jeżeli bełkocę, jakbym był

4 Chociaż i tak jest jej dużo w porównaniu z dyskursem epifanicznym Tadeusza Różewicza, w którym akcentuje się - jak pisze Dariusz Szczukowski (2008: 211) - „intensywne poczucie nietożsamości i wywłaszczenia" (o epifanii Miłosza w kontekście epifanii Różewicza zob. tamże: 210-213). 
pierwszym, który wyłoni się z iłu na brzegach oceanu? Na co zdały się cywilizacje Słońca, czerwony pył rozpadających się miast, zbroje i motory w pyle pustyń, jeżeli nie dodały nic do tego dźwięku: jest?

Wysiadła na Raspail. Zostałem z ogromem rzeczy istniejących. Gąbka, która cierpi, bo nie może napełnić się wodą, rzeka, która cierpi, bo odbicia obłoków i drzew nie są obłokami i drzewami.

Brie-Comte-Robert, 1954

(Miłosz 2011: 378)

Błoński wpisuje ten utwór w porządek epifanicznej twórczości Miłosza, związanej z próbami ocalenia niepowtarzalności bytu. Esse wyznaczałby początek drogi, zdominowanej jeszcze przez „pragnienie magicznego zawładnięcia przedmiotem (kobietą, rośliną, krajobrazem)” (Błoński 2011: 64), które ulegnie później sublimacji ograniczającej poetyckie ego, by ostatecznie „uspołecznić się", przekształcić się w „ocalanie innych dla innych” (tamże: 65). Kto wie, czy w przypadku Esse początkowa pożądliwość ego nie przyczyniła się do przeżycia epifanii w końcu szczęśliwej, głoszącej przede wszystkim triumf istnienia.

Połączony ze zdumieniem skoncentrowany podziw wyrzuca patrzącego poza miejsce i czas („przebiegały stacje metra, nie zauważałem ich”), co intensyfikuje tylko pragnienie ${ }^{5}$, by wzrok miał "siłę absolutną", by mógł nie tylko pochłonąć to piękno, lecz także niemal „wyssać” jego indywidualną poszczególność i zostawić jedynie „wydmuszkę” formy ogólnej, uproszczony jej schemat („hieroglif”). W kontekście utworu dążenie do zobaczenia w kobiecej twarzy platońskiej idei, o której pisał Stróżewski, przedstawia się niemal wampirycznie ${ }^{6}$. Towarzyszy mu zarazem pragnienie przeciwstawne - przenieść tę twarz w cały świat zewnętrzny („mieć ją na tle wszystkich gałęzi wiosennych, murów, fal”) i wewnętrzny: uczynić obiektem własnej narracji, w której ma się całkowitą władzę nad czasem („mieć ją [...] w płaczu, w śmiechu, w cofnięciu jej o piętnaście lat, w posunięciu naprzód o trzydzieści lat").

Patrzący ma świadomość niemocy wzroku, więc zostaje mu tylko nieudolna próba opisu, jakby cała tradycja terminowania w tych umiejętnościach („tony, katedry stronic”), cały czas i historia człowieka („cywilizacje Słońca, czerwony

5 Zdaniem Błońskiego (2011: 56-59) w Esse w szczególnie wyrazisty sposób ujawnia się erotyczne, zmysłowe źródło Miłoszowych objawień, połączone z pragnieniem pochłonięcia, zawładnięcia obiektem zmysłowego pożądania, choć w tej jawności połączenia duchowego z cielesnym - jak podkreśla - tkwi szczególna siła tej poezji.

6 Według Stróżewskiego (2002: 121) ekstatyczne przeżycie piękna w Esse łączy się przede wszystkim z platońskim przeżyciem miłości, bo jej obiekt istnieje jako konkret, ale także jako oczyszczona z przypadkowości jego idea. 
pył rozpadających się miast, zbroje i motory w pyle pustyń") nie miały znaczenia, jakby wiecznie było się na początku i poza stwierdzeniem oczywistości, że coś „jest” - niczego nie można było powiedzieć. Jednak wielokrotne podkreślanie niemocy i nieporadności nie mają tutaj charakteru pesymistycznego, jak to sugeruje Kris van Heuckelom (2004: 103, 106). Ponadto w chwilowości iluminacyjnego przeżycia związanego z tym, co zmysłowe, nie akcentuje się pierwiastka demonicznego, o którym pisze Błoński (2011: 59-60) jako stałym elemencie Miłoszowych epifanii. Ta epifania wydaje się wolna od nagminnego gdzie indziej przeświadczenia, że wszystko, co budzi zachwyt, jest skazane. Rację ma Stróżewski (2002: 122), że jest to doznanie przesycone radością. Tym bardziej, że radość ma tutaj charakter eksplozji, wybuchu, triumfu, jakby uczestniczyło się w wielkim akcie tworzenia świata czy światów: „Krzyczcie, dmijcie w trąby, utwórzcie tysiączne pochody, skaczcie, rozdzierajcie sobie ubrania, powtarzając to jedno: jest!". Niemożność opanowania czy nazwania doświadczanego piękna nie przekreśla zwycięskiej euforii związanej z odkrywa niem świata w sposób, jakby uczestniczyło się w pierwszym dniu stworzenia czy samemu by się Pierwszy Dzień stwarzało.

Doświadczenie Spotkania powołuje do istnienia nie tylko dziewczynę, ale i patrzącego: „ja jestem - ona jest”. Ponadto nawet po jego zakończeniu („Wysiadła na Raspail”) zostawia dar, otwiera bowiem doświadczającego na Rzeczywistość istniejącą poza relacją ,ja jestem - ona jest”. Zupełnie tak, jakby bez tego epifanijnego przeżycia nie mogła ona zaistnieć, bo dopiero dzięki niemu patrzący „zostaje z ogromem rzeczy istniejących”. Co prawda, także ze świadomością, że i one wymykają się jego władzy: „Gąbka, która cierpi, bo nie może napełnić się wodą, rzeka, która cierpi, bo odbicia obłoków i drzew nie są obłokami i drzewami". Pomimo tego obudzone przez Spotkanie pragnienie ścigania Istniejącego ma wartość rewelatorską, poświadczającą zarówno jego (tj. świata), jak i własne istnienie. W gorączkowe próby schwytania istniejącego wpisana jest wprawdzie klęska, ale i ona „wybudza” - niczym w mitach gnostyckich (Hutin 1987: 13-14) czy w filozofii Plotyna (2000: 132-133) - z odrętwienia, letargu i otwiera na kontakt z Rzeczywistością. Gnostycy czy Plotyn akt „przebudzenia” do prawdziwego życia wiązali z otwarciem się na rzeczywistość absolutną, doskonałą, ukrytą poza (lub istniejącą w nim śladowo) realnie istniejącym światem. W szczęśliwych epifaniach Miłosza (podobnie jak w Panu Tadeuszu Mickiewicza [Tomaszewska 2007: 366-433]) nie ma między tymi światami różnicy. Oczywiście można by zapytać za Bielik-Robson, jaki jest status epistemologiczny tych wizji, opóźnionych i powtórzonych w poetyckim akcie "nadania imienia”, ile jest w nich "prawdy, a ile zmyślenia” - „terapeutycznej ucieczki w królestwo subiektywnych tropów”. Ale można też powtórzyć za autorką Ducha powierzchni: „Dialektyka ta jest 
w istocie znaną od wieków dialektyką miłości: [...]. Projektuje, czy odkrywa? Czy daje się oślepić uczuciu, czy dzięki niemu dostrzega coś dotąd niewidzialnego?" (Bielik-Robson 2004: 496).

Co istotne, przykłady epifanii jednoznacznie szczęśliwych są u Miłosza wyjątkiem. Głoszony przez Bielik-Robson (2012: 13) „imperatyw wyjścia z tragedii jako układu domyślnego zachodniej refleksji” i „wykreślenie alternatywy, jaką jest mesjańska obietnica »życia powiększonego «" kreśli swoje zwycięskie ślady w poezji Miłosza, ale tylko ślady.

Być może trzeba się zgodzić, że rzeczywistość jest zdominowana przez tragiczną dwuznaczność, którą należy - jak wskazuje Sławomir Mrożek (2010: 685) - po prostu przyjąć, gdyż odmowa jej przyjęcia może wieść ku niebezpiecznie uproszczonej wizji życia, zgodnie z którą prawo do istnienia ma jedynie to, co piękne, bo zdrowe i silne. Rezultatem tęsknoty do jednoznaczności może być także jednoznaczność prowadząca do zgody na infantylną, unikającą problematyczności wizję życia, z której usuwa się wszystko, co negatywne i w efekcie - jak twierdzi Jean Baudrillard (2009: 119) - „przypieczętowuje własny zgon”. A jednak to dobrze, że pełnej świadomości niemocy wyzwolenia się z udręki dwuznaczności towarzyszy Miłoszowa, organiczna wprost niezgoda. Bo może tylko w Miłoszowym "genetycznym nieprzystosowaniu” mieści się przestrzeń litości dla ludzkiej trwogi przed bezpośrednim spotkaniem z formami dwuznaczności. Może tylko dramatyczna niezgoda tworzy jedyną przestrzeń otwartą na uprawiane przez człowieka formuły egzorcyzmów, w których zawiesza się - choćby na moment - nieuniknione.

\section{BIBLIOGRAFIA}

Baudrillard, J. (2009). Przejrzystość zła. Esej o zjawiskach skrajnych. Warszawa: Wydawnictwo Sic!

Biedrzycki, K. (2011). Miasto bez imienia. W: A. Fiut (red.), Poznawanie Miłosza 3. 1999-2010 (s. 408-551). Kraków: Wydawnictwo Literackie.

Bielik-Robson, A. (2004). Duch powierzchni. Rewizja romantyczna i filozofia. Kraków: TAiWPN Universitas.

Bielik-Robson, A. (2008). Romantyzm, niedokończony projekt. Eseje. Kraków: TAiWPN Universitas.

Bielik-Robson, A. (2012). Erros. Mesjański witalizm i filozofia. Kraków: TAiWPN Universitas.

Bieńkowska, E. (1979). Usta ciemności. Znak, nr 1-2, 83-109.

Błoński, J. (2011). Miłosz jak świat. Kraków: Społeczny Instytut Wydawniczy Znak. Chwin, S. (2012). Miłosz. Interpretacje i świadectwa. Gdańsk: Wydawnictwo Tytuł. 
Franaszek, A. (2014). Nie wejdziem do królestwa, gdzie poezja czysta. Gazeta Wyborcza. Magazyn Świateczny, nr 142. Pobrane z: https://wyborcza.pl/magazyn/1,124059,16183842,Nie_wejdziem_do_krolestwa_gdzie_poezja_czysta.html (dostęp: 10.07.2020).

Heuckelom, K. van (2004). „Patrzeć w promień od ziemi odbity”. Wizualność w poezji Czesława Miłosza. Warszawa: IBL PAN.

Hutin, S. (1987). Gnostycy. Literatura na Świecie, nr 12, 12-48.

Ingarden, R. (1960). O dziele literackim. Badania z pogranicza ontologii, teorii jezzyka i filozofii literatury. Warszawa: Państwowe Wydawnictwo Naukowe.

Jastrzębski, J. (2011). „Być samym czystym patrzeniem bez nazwy”. W: A. Fiut (red.), Poznawanie Miłosza 3. 1999-2010 (s. 236-250). Kraków: Wydawnictwo Literackie. Jung, C.G. (1995). Odpowiedź Hiobowi. Warszawa: Wydawnictwo Ethos.

Kierkegaard, S. (2010). Albo-albo (T. 1). Warszawa: Wydawnictwo Naukowe PWN.

Klejnocki, J. (2011). Wobec Nieuchronnego. O jednym wierszu Czesława Miłosza. W: A. Fiut (red.), Poznawanie Miłosza 3. 1999-2010 (s. 632-639). Kraków: Wydawnictwo Literackie.

Markowski, M.P. (2013). Polityka wrażliwości. Wprowadzenie do humanistyki. Kraków: TAiWPN Universitas.

Miłosz, C. (1980). Widzenia nad Zatoka San Francisco. Paryż: Instytut Literacki.

Miłosz, C. (1990). Rodzinna Europa. Warszawa: Czytelnik.

Miłosz, C. (2002). Druga przestrzeń. Kraków: Społeczny Instytut Wydawniczy Znak.

Miłosz, C. (2010). Rosja. Widzenia transoceaniczne (T. 1: Dostojewski-nasz współcze$s n y)$. Warszawa: Fundacja Zeszytów Literackich.

Miłosz, C. (2011). Wiersze wszystkie. Kraków: Społeczny Instytut Wydawniczy Znak.

Mrożek, S. (2010). Dziennik (T. 1: 1962-1969). Kraków: Wydawnictwo Literackie.

Nowosielski, J. (2013). Zagubiona bazylika. Refleksje o sztuce i wierze. Kraków: Społeczny Instytut Wydawniczy Znak.

Nycz, R. (2001). Literatura jako trop rzeczywistości. Poetyka epifanii w nowoczesnej literaturze polskiej. Kraków: TAiWPN Universitas.

Pilch, A. (2008). O rozpoznawaniu i urzeczywistnianiu wartości w poezji współczesnej. Pytania o wartości w szkolnej polonistyce. W: A. Janus-Sitarz (red.), Wartościowanie a edukacja polonistyczna (s. 145-159). Kraków: TAiWPN Universitas.

Plotyn (2000). Enneady I-III. Warszawa: Akme.

Ricoeur, P. (1986). Symbolika zła. Warszawa: Pax.

Scholem, G. (1997). Mistycyzm żydowski i jego główne kierunki. Warszawa: Czytelnik. Sławek, T. (2011). Bóg, przyjaźń, myśl. Czytając Blake’a i Miłosza. W: A. Fiut (red.), Poznawanie Miłosza 3. 1999-2010 (s. 59-80). Kraków: Wydawnictwo Literackie.

Stala, M. (2011). Ekstaza o wschodzie słońca. W kręgu głównych tematów poezji Czesława Miłosza. W: A. Fiut (red.), Poznawanie Miłosza 3. 1999-2010 (s. 109-171). Kraków: Wydawnictwo Literackie.

Stróżewski, W. (2002). Wokót piękna. Szkice z estetyki. Kraków: TAiWPN Universitas. Szczukowski, D. (2008). Tadeusz Różewicz wobec niewyrażalnego. Kraków: TAiWPN Universitas. 
Pobrane z czasopisma Annales N - Educatio Nova http://educatio.annales.umcs.pl Data: 26/04/2023 15:49:31

Tomaszewska, G.B. (2007). Jak widzi dusza? Estetyka i metafizyka światła w „Panu Tadeuszu". Gdańsk: Wydawnictwo Uniwersytetu Gdańskiego.

Tomaszewski, M. (1998). Od chaosu do kosmosu. Szkice o literaturze polskiej i francuskiej XX wieku. Warszawa: IBL PAN.

Zarębianka, Z. (2014). Wtajemniczenia (w) Mitosza. Pamięć - duch(owość) - wyobraźnia. Kraków: Wydawnictwo Homini. 